\title{
Pembuktian
}

\section{Kesalahan Korporasi dalam Tindak Pidana Korupsi}

\section{HARIMAN SATRIA}

Universitas Muhammadiyah Kendari

hariman85antikorupsi@gmail.com

p-ISSN 2477-118X

e-ISSN 2615-7977

\section{A B S T R A K}

Di Indonesia ada 2 putusan pengadilan terkait dengan pemidanaan korporasi dalam tindak pidana korupsi yakni Putusan PT GJW dan Putusan PT CND. Dalam kedua putusan itu, kesalahan (mens rea) korporasi dinyatakan terbukti sehingga dikenai pertanggungjawaban pidana. Kajian ini difokuskan pada cara pembuktian kesalahan korporasi dalam tindak pidana korupsi. Untuk mengurai permasalahan maka kajian ini menggunakan metode penelitian normatif dengan dua pendekatan yakni pendekatan kasus dan pendekatan konseptual. Hasil penelitian menunjukkan bahwa: pertama, dalam menentukan kesalahan korporasi, menitikberatkan pada kesalahan yang dilakukan oleh pengurus korporasi, seperti direktur. Sehingga kesalahan direktur adalah juga sebagai kesalahan korporasi. Kedua, bila dikaitkan dengan teori pertanggungjawaban pidana korporasi maka majelis hakim pada dua perkara korupsi tersebut telah mengadopsi teori identifikasi. Ketiga, perbuatan melawan hukum yang merugikan keuangan negara dan dilakukan 
oleh direktur sebagai pengurus dianggap sama dengan yang dilakukan oleh korporasi. Keempat, mengenai sanksi pidana pokok, dalam dua putusan a quo adalah sama yakni pidana denda. Kelima, dalam putusan PT GJW selain pidana pokok, korporasi juga masih dikenai pidana tambahan berupa penutupan seluruh atau sebagian perusahaan. Sedangkan dalam putusan PT CND tidak ada sama sekali sanksi pidana tambahan yang dikenakan kepada terdakwa. Keenam, kedua putusan tersebut, tidak memuat pidana tambahan berupa pembayaran uang pengganti, padahal sebagaimana diketahui bahwa salah satu cara memulihkan kerugian keuangan negara adalah melalui pidana pembayaran uang pengganti.

Kata Kunci: Pembuktian, Kesalahan Korporasi, Tindak Pidana Korupsi.

\section{A B S T R A C T}

In Indonesia there are 2 court decisions related to the punishment of corporation crimes in corruption, namely the Decision of PT GJW and the Decision of PT CND. In both decisions, the corporation mens rea is proven to be subject to criminal accountability. This study focuses on ways to prove corporation mens rea in corruption. To unravel the problem, this study uses a normative research method with two approaches namely the case approach and the conceptual approach. The results of the study: first, determining corporation mens rea, focus on mistakes made by corporation administrators, such as directors, so that the director's mistake is also a corporation mistake. Second, if it related to the corporate criminal liability theory, in the two corruption cases has adopted the theory of identification. Third, acts against the law that are detrimental to state finances and carried out by directors as administrators are considered the same as those carried out by corporations. Fourth, regarding the principal penalties, in two sentences is the same, namely fine. Fifth, in the decision of PT GJW the corporation is still subject to additional penalties in the form of closing all or part of the company. Whereas in the decision of PT CND, there is no additional penalties imposed on the defendant. Sixth, both of those decisions, do not contain additional penalties in the form of substitute money payments, even though as is known that one way to recover losses in state finances is through the payment of compensation.

Keywords: Evidence, Corporation Mens Rea, Corruption. 


\section{A. PENDAHULUAN}

Pada saat ini eksistensi korporasi dirasa semakin penting dan strategis, selain dapat membantu perputaran roda ekonomi, korporasi juga telah menjangkau hampir semua ranah kehidupan. Di Indonesia, korporasi bergerak di berbagai bidang, misalnya pendidikan, sosial, jasa konstruksi, pengangkutan dan komunikasi. Dalam konteks ini, korporasi mampu menciptakan lapangan kerja dan mengurangi pengangguran (Satria, 2017:14). Selain dampak positif, korporasi juga berdampak negatif terlibat dalam berbagai kejahatan, misalnya korupsi dan pencucian uang. Kehadiran korporasi ibarat pisau bermata dua, di satu sisi ia berdampak positif tetapi disisi lain ia juga berdampak negatif (Amrullah, 2018:6).

Peran korporasi dalam tindak pidana korupsi, dijelaskan oleh Francis Fukuyama: the corruption wreaking havoc in these countries is a direct consequence of the behaviour of multinational companies based in rich industrialized countries that don't hesitate to hand out generous bribery (Fukuyama, 2014:82-83). Uraian Fukuyama bersesuaian dengan Simon dan Eitzen, bahwa permasalahan korupsi antara negara yang dilakukan oleh korporasi raksasa dalam usaha menyuap melibatkan tokoh birokrat atau penguasa di negara bersangkutan, jadi bukan kaum politisi saja. Dikatakan bahwa kejahatan korupsi yang dilakukan oleh korporasi dapat diibaratkan layaknya penyakit kanker yang jika tidak ditangani dini, akan merusak seluruh kerangka dan struktur serta moralitas dari suatu masyarakat (Sahetapy, 2002:40-42).

Di berbagai negara telah diatur dalam sistem hukum pidananya ihwal korporasi sebagai subjek delik sehingga dapat dikenai pertanggungjawaban pidana (Fisse dan Braithwaite, 1993:12). Di Indonesia mengenai hal ini diatur dalam UU No. 31 Tahun 1999 sebagaimana telah diubah dengan UU No. 20 Tahun 2001 tentang Pemberantasan Tindak Pidana Korupsi (UU antikorupsi). Peraturan untuk memidana korporasi yang melakukan tindak pidana korupsi. Sejak diundangkannya peraturan antikorupsi tersebut, tercatat hanya ada 4 korporasi yang diproses pidana. Satu korporasi yakni PT Nusa Konstruksi Engineering ditersangkakan oleh Komisi Pemberantasan Korupsi tahun 2017. Sedangkan 3 korporasi dituntut pidana yakni: pertama, PT Girijaladhiwana dalam Putusan No. 812/Pid.Sus/2010/ PN. BJM). Kedua, PT Cakrawala Nusadimensi dalam Putusan No. 
65/Pid.Sus/TPK/2016/PN.Bdg. Ketiga, PT Indosat Mega Media dalam putusan No. 01/Pid.Sus/2013/PN.JKT. PST. Ketiga putusan tersebut mengulas pembuktian kesalahan (mens rea) korporasi sehingga dikenai pertanggungjawaban pidana. Dalam kajian ini hanya akan diulas 2 putusan yakni Putusan PT Girijaladhi Wana dan PT Cakrawala Nusa Dimensi.

\section{Rumusan Masalah}

Merujuk pada uraian tersebut di atas, maka permasalahan yang akan dicari dan ditemukan jawabannya adalah bagaimanakah cara perumusan kesalahan korporasi dalam tindak pidana korupsi sehingga dimintai pertanggungjawaban pidana?

\section{Tujuan Kajian}

Adapun tujuan kajian ini adalah untuk memberikan wacana yang utuh mengenai pembuktian kesalahan korporasi dalam tindak pidana korupsi yang dikonstruksi dari putusan pengadilan sebagai jurisprudensi. Kajian ini diharapkan mampu menstimulasi perumusan kesalahan korporasi secara normatif yang seharusnya dimuat dalam peraturan antikorupsi Indonesia ke depan.

\section{Metode Penelitian}

Morris L. Cohen dan Kent C. Olson mendefinisikan penelitian hukum sebagai the process of identifing and retrieving information necessary to support legal decision-making (Cohen \&Olson, 1992:1). Berangkat dari pemikiran Cohen tersebut, maka usulan penelitian ini merupakan penelitian hukum (legal research). Penelitian ini merupakan penelitian hukum normatif (normative law research). Untuk menjawab masalah dalam kajian ini, penulis menggunakan dua metode pendekatan. Pertama, pendekatan kasus (case approach, bertolak pada ratio decidendi yaitu alasan hukum yang digunakan oleh hakim sampai pada putusannya (Mcleod, 1999:144). Kedua, pendekatan konseptual (conceptual approach) bertolak dari pandangan-pandangan dan doktrin-doktrin yang berkembang dalam ilmu hukum. Pemahaman terhadap pandangan dan doktrin tersebut dapat menjadi sandaran dalam membangun dan memecahkan permasalahan penelitian (Marzuki, 2014:95). 


\section{Penelitian Terdahulu}

Berdasarkan hasil penelusuran kepustakaan baik secara elektronik maupun cetak, bahwa paling tidak ada 3 penelitian dalam bentuk lain tetapi memiliki korelasi dengan kajian penulis yakni sebagai berikut:

a. Penelitian yang dilakukan Lakso Anindito, mengambil judul: Lingkup Tindak Pidana Korupsi dan Pembuktian Kesalahan Dalam Sistem Pertanggungjawaban Pidana Korporasi di Indonesia, Inggris dan Perancis, Jurnal Integritas Vol o3 Nomor 1 Maret 2017, Jakarta.

b. Penelitian yang dilakukan Pusat Kajian Antikorupsi Fakultas Hukum UGM, mengambil judul: Pemidanaan Korporasi Atas Tindak Pidana Korupsi di Indonesia, Pukat Korupsi Fakultas Hukum UGM, 2013, Yogyakarta.

c. Penelitian yang dilakukan oleh Bettina Yahya, dengan judul: Pembuktian Tindak Pidana Korupsi yang Dilakukan Oleh Korporasi Sebagai Upaya Pengembalian Kerugian Keuangan Negara, Disertasi Pada Fakultas Hukum UGM, 2017, Yogyakarta.

\section{KERANGKA TEOR I}

\section{a. Konsep Tentang Pembuktian}

Berbicara tentang pembuktian maka fokusnya pada tiga hal penting yakni terminologi pembuktian; parameter pembuktian dan alat-alat bukti dalam hukum acara pidana Indonesia. PERTAMA, terminologi pembuktian. W.J.S. Poerwadarminta mengatakan bahwa kata pembuktian berasal dari suku kata bukti yang artinya sesuatu hal yang cukup untuk memperlihatkan kebenaran suatu peristiwa. Sedangkan pembuktian berarti perbuatan atau cara membuktikan (Poerwadarminta, 1990:184). Dalam bahasa Belanda, bukti disebut sebagai bewijs (evidence) berarti hal yang menunjukan kebenaran yang diajukan oleh penuntut umum atau terdakwa untuk kepentingan pemeriksaan di sidang pengadilan. Sedangkan pembuktian disebut sebagai proof yang artinya penetapan kesalahan terdakwa berdasarkan alat bukti, baik yang ditentukan oleh undangundang maupun di luar undang-undang (Hamzah, 2008:68). Bukti menyangkut hal yang menunjukkan kebenaran tentang suatu peristiwa sedangkan pembuktian (proof) menyangkut perbuatan atau cara membuktikan melalui alat-alat bukti (evidence). 
Bertalian dengan itu Ian Dennis mengatakan evidence is information to provides grounds for belief that a particular fact or set of fact is true. Proof is a term with a variable meaning. In legal discourses it may refer to outcome of the process of evaluating evidence and drawing inferences from it, or it may be used more widely to refer to the process itself and/or to the evidence which is being evaluated (Dennis, 2007:3-4).

Sedangkan Henry Campbell Black mendefinsikan proof sebagai the effect of evidence or the establishment of a fact by evidence (Campbell Black, 1968:1380). Proof pada dasarnya menyangkut tentang pembuktian artinya bagaimana alat-alat bukti (evidence) digunakan.

KEDUA, parameter pembuktian. Menurut Eddy O.S. Hiariej, terdapat enam hal yang berhubungan dengan parameter pembuktian. Pertama, bewijstheorie. Kedua, bewijsmiddelen. Ketiga, bewijsvoering. Keempat, bewijslast. Kelima, bewijskracht. Keenam, bewijsminimum (Hiariej, 2012:15-26). Bewijstheorie adalah teori pembuktian yang dipakai sebagai dasar pembuktian oleh hakim di pengadilan. Perspektif doktrin, teori pembuktian terbagi atas empat hal. Pertama, posistief wettelijk bewijstheorie yaitu pembuktian menurut undang-undang secara positif. Bambang Poernomo mengatakan bahwa pembuktian undang-undang secara positif berarti pembuktian yang sangat bergantung kepada alat-alat bukti sebagaimana disebut secara limitatif dalam undang-undang tanpa diperlukan keyakinan hakim (Poernomo, 1993:40).

Kedua, conviction in time atau pembuktian menurut keyakinan hakim melulu dimaknai sebagai sistem pembuktian yang menekankan bahwa hakim dapat menjatuhkan putusan berdasarkan keyakinan belaka dengan tidak terikat oleh suatu peraturan (Harahap, 2000:799). Ketiga, conviction rasionee adalah pembuktian berdasarkan keyakinan hakim dengan pertimbangan yang logis berarti menempatkan hakim dalam mengambil keputusan selain berdasarkan keyakinannya juga harus didukung oleh faktafakta hukum yang logis. (Harahap:2000:299). Keempat, negatief wettelijk bewijstheorie adalah hakim dalam memutuskan bersalah tidaknya terdakwa selain berdasarkan pada alat-alat bukti yang ditentukan secara limitatif oleh undang-undang juga harus diikuti 
oleh keyakinan hakim. Model pembuktian yang demikian, sejalan dengan teori pembuktian yang digunakan dalam Pasal 183 KUHAP menegaskan bahwa hakim tidak boleh menjatuhkan pidana kepada seseorang, kecuali apabila dengan sekurang-kurangnya dua alat bukti yang sah ia memperoleh keyakinan bahwa suatu tindak pidana benarbenar terjadi dan bahwa terdakwalah yang bersalah melakukannya.

KETIGA, alat-alat bukti dalam hukum acara pidana. Pembahasan tentang alat bukti pada dasarnya berhubungan dengan bewijsmiddelen yakni alat-alat bukti yang digunakan untuk membuktikan telah terjadinya suatu peristiwa pidana. Dalam hukum acara pidana Indonesia ketentuan tentang alat bukti diatur dalam Pasal 184 KUHAP yaitu sebagai berikut : pertama, keterangan saksi - Pasal 185. Kedua, keterangan ahli - Pasal 186. Ketiga, surat - Pasal 187. Keempat, petunjuk - Pasal 188. Kelima, keterangan terdakwa - Pasal 189. Khusus mengenai bukti petunjuk, ada perluasan dalam Pasal 26A UU UU Tipikor yakni alat bukti lain berupa informasi yang diucapkan, diterima, dikirim atau disimpan secara elektronik atau dengan alat optik serta bukti dokumen yang dapat dilihat, dibaca atau di dengar.

\section{b. Konsep Tentang Kesalahan dalam Hukum Pidana.}

Masalah kesalahan sesungguhnya bertalian erat dengan asas tiada pidana tanpa kesalahan atau biasa disebut dengan prinsip geen straf zonder schuld/keine straf ohne schuld. Kesalahan tidak hanya sebagai dasar dipertanggungjawabkannya pembuat/ pelaku, tetapi tidak adanya kesalahan juga menjadi dasar tidak dipertanggungjawabkannya pelaku. Ditegaskan Andrew Asworth dan Jeremy Horder, the principle that a person should not be allowed to take advantage of any defence or partial defence to criminal liability if the relevant condition or circumstance were brought by his or her own fault (Asworth dan Horder, 2013:159).

Jan Remmelink mengatakan, bahwa kesalahan sebagai dasar pencelaan yang ditujukan oleh masyarakat, menggunakan standar etis yang berlaku pada waktu tertentu terhadap orang yang melakukan perilaku menyimpang sebenarnya dapat dihindari (Remmelink, 2003:142). Bambang Poernomo dengan mengutip pendapat E. Mezger, mengatakan bahwa kesalahan bertalian dengan tiga hal, yaitu kemampuan bertanggungjawab; adanya bentuk kesalahan yang berupa kesengajaan dan culpa; tidak ada alasan penghapus kesalahan 
(Poernomo, 1993:137). Intinya kata Mezger kesalahan selalu melekat pada orang yang berbuat salah sebagaimana adagium facinus quos inquinat aequat (Sudarto, 2007:88).

Menurut Vos, kesalahan memiliki tiga pengertian. Pertama, kemampuan bertanggung jawab orang yang melakukan perbuatan. Kedua, hubungan batin tertentu dari orang yang berbuat, yang perbuatannya itu dapat berupa kesengajaan atau kealpaan. Ketiga, tidak terdapat alasan yang menghapus pertanggungjawaban bagi si pembuat atas perbuatannya itu (Poernomo, 1993:137). Atas pendapat Vos tersebut, D. Schaffmeister, et.all, menyimpulkan, bahwa kesalahan berhubungan dengan dua hal. Pertama, kesalahan dipakai sebagai syarat umum untuk dapat dipidananya perbuatan di samping sifat melawan hukum (dapat dicela). Kedua, kesalahan dipakai untuk bagian khusus rumusan delik sebagai sinonim dari sifat tidak berhatihati (Schaffmeister, 1995:85).

Secara doktrinal ada dua bentuk kesalahan yaitu kesengajaan dan kealpaan. Ihwal definisi kesengajaan dikenal dua teori yakni teori kehendak (wilstheorie) yang dipelopori oleh von Hippel dari Gottingen, Jerman dan Simons di Belanda. Teori lain adalah teori membayangkan (voorstellingstheorie) diperkenalkan oleh Frank, guru besar di Tubingen Jerman tahun 1910. Mendapat sokongan kuat dari von Listz di Jerman dan van Hamel di Belanda (Moeljatno, 2008:185). Dalam tulisan ini hanya dijelaskan 4 (empat) bentuk yang sering diulas oleh Eddy O.S. Hiariej, yakni:

Pertama, kesengajaan sebagai maksud. Kedua, kesengajaan sebagai kepastian. Ketiga, kesengajaan sebagai kemungkinan. Keempat, dolus eventualis. Kesengajaan sebagai maksud (opzet als oogmerk) adalah kesengajaan untuk mencapai suatu tujuan. Artinya motivasi seseorang melakukan perbuatan, tindakan dan akibatnya benar-benar terwujud. Sedangkan kesengajaan sebagai kepastian atau keharusan (opzet bij noodzakelijkheids of zekerheidsbewutszijn) adalah kesengajaan yang menimbulkan dua akibat. Akibat pertama dikehendaki oleh palaku sedangkan akibat kedua tidak dikehendaki namun pasti terjadi. Tipe kesengajaan selanjutnya adalah kesengajaan sebagai kemungkinan. Artinya kadang kala suatu kesengajaan menimbulkan akibat yang tidak pasti terjadi namun merupakan suatu kemungkinan. Tipe kesengajaan yang terakhir adalah dolus eventualis atau 
kesengajaan bersyarat yaitu seseorang melakukan perbuatan namun sama sekali tidak menghendaki akibatnya. Jika akibat yang tidak dikehendaki itu timbul, maka orang tersebut harus berani memikul risikonya (Hiariej, 2016:166).

Bentuk kesalahan yang lain adalah kealpaan (culpa). Adagium latin mengatakan imperetia culpae anumeratur, artinya kealpaan adalah kesalahan. Pendapat lain perihal culpa dikemukakan oleh Noyon dan Langemeijer sebagaimana dikutip oleh Eddy O.S. Hiariej, bahwa ada tiga hal yang terkandung dalam kealpaan.

Pertama, kesalahan meliputi pengertian yang sangat luas di luar kesengajaan. Kedua, dalam kesengajaan ada kehendak, sedangkan dalam kealpaan tidak ada kehendak. Ketiga, kata schuld dalam literatur hukum Belanda dapat diartikan sebagai kesalahan dan dapat juga diartikan sebagai kealpaan. Kesalahan dalam pengertian yang luas meliputi kesengajaan (dolus) dan kealpaan (culpa), sedangkan dalam pengertian yang sempit, kesalahan dapat diartikan sebagai culpa atau kealpaan (Hiariej, 2016:189).

Pembedaan kesengajaan dengan kealpaan kemudian dilakukan oleh Jan Remmelink yang berkata bahwa dolus dan culpa adalah dua kutub yang berseberangan. Pelaku dolus menghendaki akibat yang diancamkan pidana, sedangkan pelaku culpa tidak menghendaki akibat yang dianggap tidak pantas oleh perundang-undangan (Remmelink, 2003:179). Van Hamel mengatakan terkait dengan jenis culpa, ada dua bentuk yaitu culpa lata dan culpa levis. Culpa lata adalah kealpaan yang memberatkan, sedangkan culpa levis adalah kealpaan yang meringankan. Selain kedua jenis culpa ini, ada pula dikenal kealpaan yang disadari (bewuste culpa) dan kealpaan yang tidak disadari atau onbewuste culpa (Moeljatno, 2008:219).

\section{c. Konsep Tentang Pertanggungjawaban Pidana Korporasi.}

Secara etimologis, kata korporasi berasal dari bahasa latin, corporatio. Kata ini berasal dari bahasa latin yang lebih tua yakni corporare. Corporare sendiri berasal dari kata corpus yang berarti memberikan badan atau membadankan (Stone, 2005:17). Dari kata corporatio diterjemahkan ke berbagai bahasa di Eropa, seperti corporatie (Belanda), corporation (Inggris), corporation (Jerman). 
Kata corporatie (Belanda) akhirnya diterjemahkan ke dalam bahasa Indonesia menjadi korporasi. Thomas W. Dunfee mendefinisikan korporasi sebagai personae fictie, latin for fictious legal persons entities which the law threat, in most cacses, as being separate and distinct from the shareholders who own them (Sjawie, 2013:32).

Awalnya gagasan pertanggungjawaban pidana korporasi mengalami penolakan dengan berpegang pada asas universitas delinquere non potest artinya korporasi tidak dapat dipidana. Asas societes delinqere non potest artinya korporasi tidak mungkin melakukan tindak pidana, yang sangat dipengaruhi oleh ajaran Friedrich Carl von Savigny. Savigny berpendapat bahwa badan hukum hanyalah suatu fiksi saja (persona ficta; legal fiction). Bahwa kepribadian hukum sebagai satu kesatuan dengan manusia hanya khayalan semata. Kepribadian sebenarnya hanya ada pada manusia (Remmelink, 2003:272).

Sementara itu, D. Schafmeister, et.all menyebutkan bahwa proses penerimaan korporasi sebagai subjek hukum pidana terbagi dalam tiga tahap. Pertama, yaitu sejak KUHP dibentuk tahun 1886. Pada tahap ini ditandai dengan usaha-usaha agar perbuatan pidana yang dilakukan badan hukum, dibatasi pada perorangan (naturalijek persoon). Kedua, pasca Perang Dunia I. Pada tahap ini dalam undang-undang telah ditentukan bahwa suatu perbuatan pidana dapat dilakukan oleh korporasi namun tanggung jawab untuk itu masih menjadi beban dari pengurus atau anggota pimpinan dari badan hukum tersebut. Ketiga, pada waktu dan sesudah Perang Dunia II, tanggung jawab pidana langsung dari korporasi dianut juga (Schaffmeister, et.all, 1995:274-276).

Pengakuan korporasi sebagai subjek hukum pidana, berikut tahapan pertanggungjawabannya yang dikemukakan oleh Schaffmeister et.all, dapat kita simpulkan bahwa korporasi dapat melakukan kejahatan, karena ia mulai diakui sebagai subjek hukum sehingga dapat dimintai pertanggungjawaban pidana. Pertanyaan kemudian adalah apakah kejahatan korporasi itu? Sally S. Simpson, mengatakan corporate crime is type of white collar crime (Simpson, 2005:6). Demikian pula John Braithwaite, mengatakan bahwa corporate crime is the conduct of a corporation, or of employees acting on behalf of a corporation, which is prescribed and punishable by law (Braithwaite, 1984:6) 
Secara teoritis dikenal tiga prototipe kejahatan korporasi. Pertama, crimes for corporation adalah kejahatan untuk korporasi. Kedua, crimes against corporation artinya kejahatan terhadap korporasi. Ketiga, criminal corportions artinya korporasi yang sejak semula dibentuk untuk melakukan kejahatan (Simpson \& Weisburd, 2009:3). Pada dasarnya, ada lima teori pertanggungjawaban pidana korporasi yakni: Pertama, teori identifikasi (identification theory) disebut dengan direct corporate criminal liablity. Menurut teori ini korporasi bisa melakukan sejumlah delik secara langsung melalui pengurus yang berhubungan erat dengan korporasi, bertindak untuk dan atas nama korporasi sehingga dipandang sebagai korporasi itu sendiri (Reid, 1995:53).

Kedua, strict liability. Smith dan Brian Hogan, mendefinisikan strict liability sebagai crimes which do not require intention, recklesness or even ngeligent or more element in the actus reus (Smith \& Hogan, 1998:79). Intinya strict liability diartikan sebagai pertanggungjawaban yang ketat menurut undang-undang tanpa memandang siapa yang melakukan kesalahan. Ketiga, vicarious liability. Ajaran ini erat hubungannya dengan doctrine of respondeat superior yaitu adanya hubungan antara master dan servant atau antara principal dan agent. Hubungan itu kemudian dikuatkan oleh adagium yang berbunyi qui facit per alium facit per se artinya seseorang yang berbuat melalui orang lain dianggap dia sendiri yang melakukan perbuatan itu (Sjadeini, 2006:84). Hal ini sejalan dengan pendapat Wayne R. LaFave, vicarious liability is one wherein one person, though without personal fault, is more liable for the counduct of another (LaFave, 2003:224). Dengan demikian doktrin ini merupakan pengecualian pertanggungjawaban individu yang dianut dalam hukum pidana berdasarkan adagium nemo punitur pro alieno delicto artinya: tidak ada seorang pun yang dihukum karena perbuatan orang lain.

Keempat, teori agregasi. Ajaran ini menekankan bahwa semua perbuatan dan semua unsur mental (mens rea) dari berbagai orang yang terkait secara relevan dalam lingkungan perusahaan dianggap dilakukan oleh satu orang saja. (Clarkson \& Keating, 2007:242260). Kelima, doktrin corporate cultural model atau model budaya kerja. Doktrin ini berasal dari KUHP Australia: corporate culture is an attitude, policy, rule, course of conduct or practice existing within the body corporate generally or within the area of the body 
corporate in which the relevant activities take places. (Article 51:4). Intinya adalah kebijakan badan hukum mempengaruhi cara kerja badan hukum tersebut.

\section{d. Konsep Tentang Tindak Pidana Korupsi}

Secara etimologis, korupsi berasal dari bahasa latin, corruptio atau menurut webstudent dictionary adalah coruptus. Dijelaskan bahwa corruptio berasal dari suatu kata latin yang lebih tua yaitu corumpere dan turun dalam berbagai bahasa di eropa, seperti Inggris: corruption, corrupt; Perancis: corruption; dan Belanda yaitu corruptie (korruptie). Dapat diduga kata korupsi yang digunakan di Indonesia saat ini berasal dari bahasa Belanda yang kemudian diadopsi atau diterima ke dalam bahasa Indonesia yaitu "korupsi" (Hamzah, 2007:4). Secara harfiah kata-kata tersebut berarti, kebusukan, keburukan, ketidakjujuran, dapat disuap, tidak bermoral, penyimpangan dari kesucian, kata-kata atau ucapan yang menghina atau memfitnah. Secara tegas diuraikan dalam The lexicon Webster dictionary, corruption (L. corruption) The act of corrupting or the state of being corrupt; putrefactive; decomposition. Putrid matter; moral perversion; depravity; perversion of integrity; corrupt or dishonest, proceedings; bribery; perversion from a state of purity; debasement, as of a language; a debased from of a word (Hamzah, 2007:5).

Sementara itu Sanford H. Kadish, mengartikan korupsi hubungannya dengan penyuapan: corruption is the act or practice of benefiting a person in order to betray a trust or to perform a duty meant to be performed freely, bribery occurs relation to a public official and, derivatively, in private transaction (Kadish, 1983:119). Istilah dan arti kata korupsi akhirnya diterima dalam perbendaharaan kata Bahasa Indonesia yang oleh Poerwadarminta, kata korupsi dimaknai sebagai perbuatan yang buruk seperti penggelapan uang, penerimaan uang sogok dan sebagainya (Poerwadarminta, 1990:616).

Dalam UU antikorupsi Indonesia, tidak memberikan definisi yang pasti dan ketat mengenai pengertian korupsi. Peraturan tersebut hanya mengkualifikasikan 30 perbuatan yang kemudian disebut sebagai tindak pidana korupsi. Diantara 30 perbuatan tersebut dikenal beberapa tipe korupsi, misalnya korupsi perbuatan curang, korupsi gratifikasi, korupsi penyuapan, korupsi menyalahgunakan wewenang dan korupsi karena perbuatan melawan hukum (Satria, 
2017:93)). UNCAC 2003 yang kemudian diratifikasi melalui UndangUndang No. 7 Tahun 2006 tentang Pengesahan UNCAC 2003 tidak memberikan definisi yang strict tentang korupsi. Namun dalam konvensi ini telah menyebutkan ragam perbuatan yang dapat dikualifikasi sebagai korupsi.

Pertama, Bribery of national public official atau penyuapan pejabat-pejabat publik nasional. Kedua, bribery of foreign public officials and official of public international organizations atau penyuapan pejabat-pejabat publik asing dan pejabat-pejabat dari organisasi internasional publik. Ketiga, embzellment, misappropriation or other diversion of property by public official atau penggelapan, penyelewengan atau pengalihan kekayaan dengan cara lain oleh pejabat publik. Keempat, trading in influence atau memperdagangkan pengaruh. Kelima, abuse of function atau penyalahgunaan fungsi. Keenam, illicit enrichment atau memperkaya diri secara tidak sah. Ketujuh, bribery in the privat sector atau penyuapan pada sektor swasta. Kedelapan, emblezzement of property in the privat sector atau penggelapan kekayaan dalam sektor swasta. Kesembilan, laundering of proceeds of crime atau pencucian hasil kejahatan. Kesepuluh, concealment atau penyembunyian. Kesebelas, obstruction of justice atau perbuatan menghalang-halangi proses peradilan (UNODC, 2003:17-21).

\section{B. PEMBAHASAN}

\section{Kajian terhadap Putusan PT Giri Jaladhi Wana (PT GJW)}

Perlu penulis sampaikan bahwa PT.GJW dituntut pidana sesudah adanya putusan Mahkamah Agung dalam tingkat Kasasi No.936.K/ Pid.Sus/2009 tanggal 25 Mei 2009 yang sudah berkekuatan hukum tetap yang menjatuhkan putusan bersalah serta mempidana terhadap 4 (empat) terdakwa selaku pengurus korporasi PT.GJW yaitu Direktur Utama (Stephanus Widagdo), Direktur (Bonafacius Tjiptomo Subekti), mantan Walikota Banjarmasin (Midfai Yabani), dan Kepala Dinas Pasar Kota Banjarmasin (Edwan Nizar).

Kasus yang melibatkan PT GJW bermula dari kontrak dengan Pemerintah Kota Banjarmasin mengenai pembangunan Pasar Sentra Antasari pada tahun 1998. Penandatanganan kontrak dilakukan Direktur Utama PT GJW bernama Stevanus Widagdo, No. 003/ 
GJW/VII/1998 tentang kontrak bagi tempat usaha dalam rangka pembangunan pasar Sentra Antasari Kota Banjarmasin. Sedangkan pemerintah Kota Banjarmasin diwakili oleh H. Sadjoko selaku Walikota Banjarmasin. Dalam perkembangannya PT GJW diduga melakukan tindak pidana korupsi yang merugikan keuangan negara atau daerah Kota Banjarmasin. Tindak pidana korupsi tersebut dilakukan oleh PT GJW melalui beberapa penyimpangan kontrak antara lain:

a. PT GJW diwajibkan membangun Pasar Sentra Antasari dengan fasilitas penunjang sejumlah 5.145 unit tetapi PT GJW malah membangun sebanyak 6.045 unit sehingga ada penambahan sekitar 900 unit dan dijual dengan harga Rp. 16.691.713.,- yang hasil penjualannya tidak disetorkan ke kas daerah Kota Banjarmasin.

b. PT GJW juga tidak pernah memberikan pertanggungjawaban secara tertulis mengenai pengelolaan Pasar Sentra Antasari kepada Walikota Banjarmasin.

c. PT GJW tidak pernah membayar atau menyetorkan biaya pengelolaan Pasar Sentra Antasari ke Kas Daerah Kota Banjarmasin.

d. Selain itu, PT GJW juga berusaha sedemikian rupa untuk menutupi atau mengelabui pemerintah Kota Banjarmasin mengenai keuntungan yang diperoleh dari hasil pengelolaan Pasar Sentra Antasari, sehingga laporannya selalu merugi.

Atas perbuatan tersebut, PT GJW diduga telah merugikan keuangan negara sebanyak Rp.7.332.361.0oo,- oleh karenanya PT GJW dituntut pidana denda oleh JPU sebesar Rp. 1.300.000.000,majelis hakim kemudian menjatuhkan pidana denda, sebesar Rp. 1.300.000.000. Selain pidana denda PT GJW juga dikenai pidana tambahan berupa penutupan sementara perusahaan selama 6 bulan. Dijatuhkannya pidana denda dan pidana tambahan kepada PT GJW menunjukkan bahwa majelis hakim meyakini bahwa PT GJW patut dicela atau disalahkan ( $m e n s$ rea) atas perbuatannya yang merugikan keuangan negara. Oleh karena itu penting dilihat bagaimana majelis hakim merangkai fakta yang kemudian sampai pada kesimpulan bahwa PT GJW memang bersalah atas tindak pidana korupsi yang dilakukannya.

Rangkaian kesalahan PT GJW dapat dilihat pada ratio decidendi 
atau pertimbangan hukum majelis hakim dalam putusan No. 812/ Pid.Sus/2010/PN. BJM. Dari pertimbangan hukum majelis hakim, penulis akan memfokuskan pada konstruksi fakta persidangan yang mengarah pada kesimpulan bahwa PT GJW memang memiliki kesalahan (mens rea) sehingga harus dituntut pidana guna dimintai pertanggungjawaban pidana. Artinya bahwa perbuatan PT GJW selain telah memenuhi rumusan delik (actus reus), terpenuhi unsur kesalahan (mens rea) sehingga harus dikenai pertanggungjawaban pidana. Adapun rangkaian kesalahan PT GJW sehingga dikenai pertanggungjawaban pidana adalah sebagai berikut:

a. Bahwa PT GJW telah mengikatkan diri dalam suatu kontrak dengan Pemerintah Kota Banjarmasin untuk pembangunan Pasar Sentra Antasari yang diwakili oleh Direktur Utama bernama Stevanus Widagdo. Tindakan Direktur Utama dalam menandatangani kontrak adalah sama saja dengan tindakan yang dilakukan oleh PT GJW.

b. Dalam melaksanakan kontrak tersebut, Direktur Utama dan Direktur yang bernama Bonafacius Tjiptomo Subekti sebagai perwakilan PT GJW telah melakukan perbuatan melawan hukum dengan cara membangun 6.045 unit rumah toko, los dan kios padahal yang tertera dalam kontrak hanya berjumlah 5145 unit. Artinya terdapat penambahan 900 unit oleh PT GJW sehingga mempengaruhi jumlah pendapatan yang diterima oleh PT GJW. Namun demikian pendapatan tersebut tidak disetorkan oleh PT GJW ke kas daerah Kota Banjarmasin sehingga terjadi kerugian negara dalam jumlah yang signifikan.

c. PT GJW melalui Direktur Utama bernama Stevanus Widagdo dan direktur Bonafacius Tjiptomo Subektitelah dengan sengaja tidak membayar uang pengelolaan Pasar Sentra Antasari kepada kas daerah pemerintah Kota Banjarmasin. Selain itu Stevanus Widagdo berulang kali memberikan keterangan yang tidak benar kepada pemerintah Kota Banjarmasin yang menyatakan seolah-olah PT GJW mengalami kerugian secara terus menerus padahal kenyataannya tidak demikian.

d. PT GJW melalui Stevanus Widagdo dan Bonafacius Tjiptomo Subekti juga melakukan berbagai macam kecurangan dan penyimpangan bertalian dengan penggunaan fasilitas kredit modal kerja dari PT Bank Mandiri Tbk. Diantaranya PT 
GJW tetap mengajukan fasilitas kredit meskipun kontraknya telah diandendum sebanyak 3 kali. PT GJW telah memberi informasi yang tidak benar kepada Bank Mandiri Tbk.

e. PT GJW dengan sengaja tidak membayar kewajiban kepada pemerintah Kota Banjarmasin berupa uang retribusi, penggantian uang sewa, pembayaran pelunasan kredit yang jumlahnya mencapai Rp. 6. 750.000.000,- namun demikian PT GJW hanya membayar Rp. 1.000.000.00o,- sehingga negara dalam hal ini pemerintah Kota Banjarmasin, dirugikan sebanyak Rp. 5·750.000.000,- padahal PT GJW telah memperoleh hasil penjualan rumah toko, los, warung dan kios sebanyak Rp. 64.579.000.000,-

f. Atas perbuatan tersebut, PT GJW dapat dikatakan melakukan perbuatan melawan hukum yang merugikan keuangan negara sebagaimana disebutkan dalam Pasal 2 ayat (1) UU Tipikor. Untuk itu PT GJW harus dikenai sanksi pidana sebagai bentuk pertanggungjawaban pidana atas perbuatannya.

Merujuk pada uraian tersebut, analisis penulis adalah bahwa penuntutan kepada PT GJW yang diwakili oleh Stevanus Widagdo selaku Direktur Utama dan Bonafacius Tjiptomo Subekti selaku direktur telah sesuai dengan ketentuan dalam Pasal 20 ayat (3) UU Tipikor. Dalam ketentuan a quo, ditegaskan bahwa dalam hal tuntutan pidana dilakukan terhadap korporasi, maka korporasi tersebut diwakili oleh pengurus. In qasu a quo diwakili oleh Stevanus Widagdo selaku direktur utama dan Bonafacius Tjiptomo Subekti selaku direktur.

Selanjutnya mengenai penentuan kesalahan (mens rea) PT GJW. Majelis hakim dalam putusan a quo secara eksplisit menekankan bahwa kesalahan direktur utama dan direktur PT GJW yang secara melawan hukum melakukan perbuatan yang tidak sesuai dengan kontrak yang ditandatangani antara PT GJW dan pemerintah Kota Banjarmasin sehingga menimbulkan kerugian keuangan negara dalam jumlah miliaran rupiah adalah kesalahan yang dapat dipertanggungjawabkan kepada PT GJW selaku korporasi. Dalam hal ini tindakan melawan hukum direktur utama sebagai salah satu elemen tindak pidana korupsi sebagaimana disebutkan dalam Pasal 2 ayat (1) jo Pasal 20 UU Tipikor adalah sama dengan tindakan melawan hukum yang dilakukan oleh PT GJW. 
Dalam hal ini, Stevanus Widagdo dan Bonafacius Tjiptomo Subekti selaku personel pengendali korporasi (directing mind and will) adalah pengurus yang dianggap identik dengan PT GJW. Sehingga tindakannya dianggap sebagai tindakan PT GJW itu sendiri. Termasuk ketika Stevanus Widagdo secara melawan hukum melakukan tindak pidana korupsi pada pembangunan Pasar Sentra Antasari Banjarmasin. Tindakan korupsi ini kemudian dipertanggungjawabkan kepada PT GJW selaku korporasi. Dalam membuktikan kesalahan PT GJW, majelis hakim menitikberatkan pada kesalahan direktur utamanya yakni Stevanus Widagdo. Atas dasar itulah Dominik Brodowski et.all mengatakan bahwa the act and state of mind of the person are the acts and state of mind of the corporation (Brodowski et.all, 2014:211).

Apabila dilihat secara normatif, cara penentuan kesalahan korporasi dalam perkara tersebut, sejalan dengan ketentuan dalam pada Pasal 20 ayat (2) UU Tipikor. Penentuan kesalahan korporasi dalam tindak pidana korupsi adalah berpatokan pada kesalahan yang dilakukan oleh pengurus korporasi. Kesalahan terjadi ketika tindak pidana dilakukan oleh orang-orang baik berdasarkan hubungan kerja maupun hubungan lain, bertindak dalam lingkup korporasi tersebut, baik sendiri-sendiri maupun bersama-sama.

Peraturan a quo, secara implisit mengadopsi 2 teori penting dalam pertanggungjawaban pidana korporasi yakni teori identifikasi (identification theory), pada farasa "apabila tindak pidana tersebut dilakukan oleh orang-orang baik berdasarkan hubungan kerja atau berdasarkan hubungan lain". Selain itu, peraturan a quo juga mengadopsi teori agregasi (aggregation theory), dalam frasa “apabila tindakan tersebut dilakukan baik sendiri-sendiri maupun bersamasama”. Bertalian dengan pemidanaan terhadap PT GJW, maka dapat penulis tegaskan bahwa penuntutan dan pemidanaan kepada Stevanus Widagdo sebagai direktur utama PT GJW dan Bonafacius T. Subekti selaku direktur seperti memberi penegasan bahwa majelis hakim mengadopsi kedua teori tersebut.

Menarik diulas adalah mengenai sanksi pidana denda kepada PT GJW sebagai pelaku tindak pidana korupsi. Dalam putusan a quo, karena PT GJW terbukti bersalah melakukan tindak pidana korupsi yang merugikan keuangan negara maka dijatuhi pidana denda sebesar Rp. 1.300.000.000,-. Jumlah ini tentu masih lebih sedikit ketimbang kerugian negara yang ditaksir mencapai Rp.7.332.361.000,-. 
Dalam kosa kata lain, jumlah sanksi pidana denda tersebut masih belum maksimal, padahal salah satu cara mengembalikan kerugian keuangan negara adalah melalui pidana denda. Mengenai pidana denda dalam tindak pidana korupsi, rujukan normatifnya adalah dalam Pasal 20 ayat (6) UU Tipikor, yang menegaskan bahwa pidana pokok yang dapat dijatuhkan kepada korporasi hanya pidana denda, dengan ketentuan maksimum pidana ditambah 1/3. Maka pidana denda kepada PT GJW masih mungkin dikenakan secara maksimal sesuai dengan peraturan a quo, misalnya dengan penambahan 1/3 dari jumlah pidana denda yang diancamkan, sehingga pengembalian kerugian negara dalam hal ini dapat maksimal.

Masalah lain bertalian dengan pidana denda kepada PT GJW adalah tidak ada alternatif pidana kurungan ketika PT GJW tidak mampu membayar pidana denda. Seharusnya JPU menuntut PT GJW dengan pidana denda subsider pidana kurungan. Pidana kurungan tidak dapat dikenakan kepada PT GJW sebab ia korporasi yang pada hakikatnya tidak mungkin dikenai pidana perampasan kemerdekaan. Pidana kurungan dapat dikenakan kepada Stevanus Widagdo sebagai directing mind and will atau personel pengendali PT GJW ketika korporasi tidak mampu membayar pidana denda yang dikenakan. Alternatif lain jika PT GJW tidak mampu membayar pidana denda adalah memberi kewenangan pada JPU menyita aset atau harta kekayaan PT GJW guna dilelang tetapi jumlahnya sama dengan pidana denda yang dijatuhkan. Sehingga kerugian keuangan negara dapat dipulihkan secara maksimal (restutio in integrum).

Masalah lain yang penulis kritik dalam putusan a quo bertalian dengan pembuktian kesalahan PT GJW adalah mengenai tidak diterapkannya sanksi pidana pembayaran uang pengganti kepada PT GJW. Padahal dakwaan dan tuntutan JPU dalam perkara $a$ quo menyertakan sanksi pembayaran uang pengganti. Namun demikian majelis hakim memutuskan tidak memberikan sanksi pidana pembayaran uang pengganti kepada PT GJW. Terdapat sikap kontradiktif antara tuntutan dakwaan dan tuntutan JPU dengan putusan hakim. Seharusnya majelis hakim ikut menjatuhkan pidana pembayaran uang pengganti kepada PT GJW. Apalagi Pasal 18 huruf b UU Tipikor memberi dasar hukum yang kuat. Pembayaran uang pengganti yang jumlahnya sebanyak-banyaknya sama dengan harta benda yang diperoleh dari tindak pidana korupsi. PT GJW pun dapat dikenai pidana pembayaran uang pengganti sebagai pidana 
tambahan, sehingga pengembalian kerugian negara dapat terlaksana maksimal.

Demikian juga mengenai pidana tambahan berupa penutupan sementara waktu PT GJW selama 6 bulan. Sanksi ini terkesan tanggung sebab jika merujuk pada Pasal 18 huruf c UU Tipikor, lamanya sanksi adalah maksimal 1 tahun. Artinya JPU hanya menuntut sanksi pidana tambahan kepada PT GJW dengan ancaman pidana yang masih rendah. Seharusnya dengan memperhitungkan kerugian keuangan negara dan memberikan efek jera kepada PT GJW sebagai korporasi, maka sanksi penutupan perusahaan seharusnya menggunakan tuntutan maksimal 1 tahun.

\section{Kajian Terhadap Putusan PT Cakrawala Nusa Dimensi (PT CND)}

Kasus tindak pidana korupsi lain yang menarik juga dianalisis adalah mengenai perkara yang melibatkan PT Cakrawala Nusa Dimensi (PT CND) dalam putusan No. 65/Pid.Sus/TPK/2016/ PN.Bdg. Secara singkat posisi kasusnya adalah sebagai berikut:

Kasus ini bermula dari permohonan PT CND kepada Walikota Bekasi untuk pembangunan perumahan atas nama PT CND seluas 4500 Ha di Kec Mustikajaya Bantargebang Kota Bekasi. Atas permohonan tersebut, Walikota Bekasi menerbitkan Surat Keputusan No. 591/Kep.162-Bipem/V/2007 tanggal 16 Mei 2007. Dengan keluarnya keputusan ini maka PT CND melakukan pembebasan lahan untuk digunakan sebagai perumahan yang dikelola oleh PT CND. Dalam proses pembebasan lahan ada tanah seluas 10.882 $\mathrm{M}^{2}$ milik pemerintah Kota Bekasi yang diperoleh dari PT Sentosa Birunusa yang juga dibeli dari pemilik asal. PT CND kemudian melakukan tukar guling dengan Pemerintah Kota Bekasi yang mana tanah milik PT CND seluas 16.500 $\mathrm{M}^{2}$ yang terletak di Sumur Batu, ditukar dengan tanah milik Pemerintah Bekasi yang terletak di TPU. Sehingga PT CND telah memiliki hak atas tanah yang sebelumnya dimiliki oleh pemerintah Kota Bekasi.

Atas perolehan dan penguasaan tanah tersebut, PT CND kemudian membuka 120 tanah kavling, PT CND juga berhasil menjual 72 unit rumah kepada konsumen dengan keuntungan yang ditaksir mencapai Rp. 2. 640.834.536,-. Dalam proses penguasaan dan pengembangan tanah PT CND tersebut diduga terjadi penyimpangan, maka dilakukan audit oleh Badan Pemeriksa Keuangan dan Pembangunan 
(BPKP). Kesimpulannya adalah tindakan PT CND telah menimbulkan terjadinya kerugian keuangan negara sebesar Rp. 4. 189.570.000, Perbuatan CND yang sudah mengetahui bahwa tanah seluas 10.882 $\mathrm{M}^{2}$ adalah aset pemerintah kota bekasi, akan tetapi PT CND tetap menandatangani surat-surat pelepasan hak sehingga seakanakan telah menerima pelepasan hak atas tanah seluas $10.882 \mathrm{M}^{2}$ dari pemiliknya. Perbuatan tersebut tentu merupakan suatu tindak pidana yang merugikan keuangan negara.

Untuk mengurai keterlibatan PT CND sehingga dikenai tuntutan pidana oleh Jaksa Penuntut Umum (JPU) maka penulis akan mengulas pertimbangan hukum (ratio decidendi) majelis hakim sehingga sampai pada kesimpulan bahwa PT CND memang dapat dicela atau disalahkan (mens rea) atas perbuatannya sehingga dapat dikenai pertanggungjawaban pidana (criminal liability). Pemidanaan kepada PT CND disebabkan adanya perbuatan melawan hukum yang merugikan keuangan negara dan perbuatan itu dapat disalahkan kepada PT CND sebagai pelaku tindak pidana korupsi.

Penulis akan berfokus pada ratio decidendi yang mengarah pada terbuktinya kesalahan PT CND sehingga dapat dikenai pertanggungjawaban pidana. Pertimbangan hukum adalah sebagai berikut:

a. Bahwa pada tahun 2002 sampai dengan tahun 2007 terdakwa PT.CND memiliki susunan pengurus berdasarkan berdasarkan Keputusan Rapat Umum Pemegang Saham Luar Biasa Perseroan pada tanggal 15 April 2002 dan Akta Notaris dalam Akta nomor 2 tanggal 6 Mei 2002 dengan Direktur YUDI WIJAYA

b. Bahwa pada tahun 2013 terdakwa PT. CND selaku pemegang sertifikat Hak Guna Bangunan (SHGB) Nomor : 576/Sumur Batu, Surat Ukur Nomor : 57/Sumur Batu/2014 tanggal 17 Juli 2014, NIB.10.26.06.04.10520 diwakili oleh Yudi Wijaya selaku Direktur, mengajukan permohonan pemisahan dan penerbitan SHGB No. 576 ke BPN Kota Bekasi untuk diterbitkan SHGB sebanyak 172 bidang. Selanjutnya atas permohonan tersebut BPN Kota Bekasi menerbitkan 172 SHGB No. 834 s/d No. 1.005 dengan total luas tanah seluruhnya 9.168 M2 yang tercatat pada buku tanah HGB No. 576.

c. Bahwa PT CND selaku korporasi bersama-sama dengan 
Gatot Sutejo mengatur secara sepihak pemindahan tanah hak milik seluas $10.882 \mathrm{M}^{2}$. Padahal tanah tersebut adalah aset Pemerintah Kota Bekasi, akan tetapi PT CND tetap menandatangani surat-surat pelepasan hak sehingga seakanakan telah menerima pelepasan hak atastanah seluas 10.882 $\mathrm{M}^{2}$ dari pemiliknya. Perbuatan ini dilakukan oleh PT CND yang bekerja sama dengan Gatot Sutejo. Perbuatan tersebut tentu merupakan suatu tindak pidana yang merugikan keuangan negara.

d. Bahwa atas perolehan dan penguasaan tanah milik Pemerintah Kota Bekasi seluas 10.882 $\mathrm{M}^{2}$ tersebut terdakwa PT.CND telah membuka 120 (seratus dua puluh) tanah Kavling dan dari jumlah dimaksud telah terbangun 79 (tujuh puluh sembilan) unit rumah komersial, yang dari jumlah unit rumah komersial terbangun dimaksud terdakwa PT. CND telah menjual 72 (tujuh puluh dua) unit rumah kepada konsumen

e. Bahwa perbuatan terdakwa PT. CND tersebut, bertentangan dengan:

1). UU No 1 Tahun 2004 Tentang Perbendaharaan Negara Pasal 45 Ayat 2 mengatur pemindahtanganan barang milik daerah/negara dilakukan dengan cara dijual, dipertukarkan, dihibahkan atau disertakan sebagai modal pemerintah setelah mendapat persetujuan DPR/DPRD”.

2). PP No. 6 Tahun 2006 Tentang Pengelolaan Barang Milik Negara/Daerah Pasal 46 Ayat 2 Huruf a mengatur pemindahtanganan barang milik daerah sebagaimana dimaksud dalam Pasal 45 untuk tanah dan/atau bangunan, dilakukan setelah mendapat persetujuan DPRD.

3). Peraturan Menteri Dalam Negeri Nomor 17 Tahun 2007 Tentang Pedoman Teknis Pengelolaan Barang Milik Daerah Pasal 58 Ayat (1) Huruf a mengatur pemindahtanganan barang milik daerah sebagaimana dimaksud dalam Pasal 57, ditetapkan dengan Keputusan Kepala Daerah setelah mendapat persetujuan Dewan Perwakilan Rakyat Daerah, untuk tanah dan/atau bangunan.

f. Bahwa perbuatan PT CND yang bekerja sama dengan Gatot Sutejo secara nyata telah menimbulkan kerugian keuangan 
negara sebesar Rp.4.189.570.000,-Oleh karenaitu, perbuatan PT CND tersebut melanggar Pasal 2 ayat (1) Jo Pasal 18 Jo Pasal 20 UU No. 31 Tahun 1999 sebagaimana telah diubah dengan UU Nomor 20 Tahun 2001 Tentang Pemberantasan Tindak Pidana Korupsi jo Pasal 55 ayat (1) ke-1 KUHP.

g.. Bahwa Terdakwa PT CND dalam persidangan ini diwakili oleh YUDI WIJAYA selaku Direktur PT CND berdasarkan Pernyataan Keputusan Rapat Umum Pemegang Saham Luar Biasa PT. CND, Akta Nomor 2 tanggal o6 Mei 2002, Notaris Titi Indrasari, SH. Berdasarkan anggaran perseroan Pasal 12 Akta No. 38 tanggal 18 Januari 2008, YUDI WIJAYA selaku Direktur antara lain berhak mewakili perseroan di dalam dan di luar pengadilan tentang segala hal dan dalam segala kejadian;

h.. Atas perbuatannya PT CND dijatuhi pidana denda sebesar Rp 700.000.000,- dengan ketentuan jika tidak membayar denda tersebut dalam tenggang waktu 1 (satu) bulan sejak putusan berkekuatan hukum tetap, maka harta benda PT CND dapat disita oleh Jaksa dan dilelang untuk membayar denda tersebut.

Berdasarkan pertimbangan hukum majelis dalam putusan a quo, penulis berkesimpulan: pertama, majelis hakim meyakini bahwa PT CND bersama-sama dengan GatotSutedjoadalah pelaku tindak pidana korupsi dengan motif tukar guling sertifikat tanah milik padahal tanah tersebut bukanlah milik PT CND melainkan milik pemerintah Kota Bekasi sehingga perbuatan PT CND tersebut merugikan keuangan negara. Majelis hakim secara eksplisit mengakui bahwa korporasi dapat saja melakukan tindak pidana korupsi melalui pengurus atau direktur utamanya. Konstruksi demikian sesungguhnya tidaklah keliru sebab sejak awal UU Tipikor telah mengenal korporasi sebagai subjek delik. Hal ini ada dalam rumusan Pasal 1 ayat 3 yang menekan bahwa setiap orang adalah orang perseorangan atau korporasi.

Kedua, model penuntutan yang dilakukan oleh JPU kepada PT CND yang diwakili oleh direktur utamanya adalah konstruksi hukum yang juga tidak keliru. Secara normatif UU Tipikor menegaskan bahwa dalam hal tuntutan pidana dilakukan terhadap korporasi maka korporasi tersebut diwakili oleh pengurus. Sehingga ketika JPU akan menuntut pidana terhadap korporasi yang diduga terlibat dalam suatu tindak pidana korupsi maka dapat diwakili oleh 
pengurus korporasi tersebut, misalnya direktur sebagai personel pengendali dalam korporasi. Sayangnya dalam UU antikorupsi tidak menyebutkan dengan jelas indikator pengurus dari suatu korporasi. Untuk memecahkan masalah ini, dalam Pasal 1 butir 10 PERMA No. 13 Tahun 2016 tentang Tata Cara Penanganan Tindak Pidana Oleh Korporasi, dijelaskan bahwa ada 3 kategori pengurus korporasi yakni sebagai berikut:

a. Organ yang mengoperasikan korporasi sesuai dengan anggaran dasar korporasi tersebut.

b. Mereka yang tidak berwenang membuat keputusan dalam korporasi tetapi dalam kenyataannya mampu mengendalikan atau mempengaruhi kebijakan korporasi.

c. Mereka yang turut memutuskan kebijakan dalam korporasi yang kemudian keputusan itu dikualifikasi sebagai tindak pidana.

Salah satu pendorong munculnya gagasan kategorisasi pengurus korporasi tersebut adalah karena korporasi hanya dapat bertindak melalui pengurusnya mulai dari tingkat yang paling tinggi seperti direktur utama hingga karyawan biasa. Secara gamblang mengenai hal ini dikemukakan oleh Low Jeffries Jr dan Bonnie, a corporation can only act through it agents (Huda, 2008:213).

Ketiga, dalam menentukan kesalahan korporasi, majelis hakim menitikberatkan pada perbuatan atau tindakan yang dilakukan oleh pengurus yakni direktur utama. Sehingga tindakan melawan hukum direktur kemudian diasosiasikan menjadi tindakan melawan hukum PT CND selaku korporasi. In qasu a quo, direktur utama PT CND yang melakukan tukar guling tanah bersertifikat, milik pemerintah Kota Bekasi sehingga seakan-akan menjadi miliknya yang merugikan keuangan negara atau daerah Kota Bekasi. Perbuatan itu dikualifikasi sebagai tindak pidana korupsi. Korupsi yang dilakukan oleh direktur utama yang bertindak untuk dan atas nama korporasi dianggap sebagai tindak pidana korupsi yang dilakukan oleh korporasi (PT CND) itu sendiri sehingga PT CND harus dikenai pertanggungjawaban pidana.

Mengenai rangkaian kesalahan dapat dilihat pada beberapa pertimbangan hukum majelis hakim seperti yang penulis uraikan di atas. Yudi Wijaya selaku direktur PT CND yang melakukan perbuatan melawan hukum dalam tukar guling tanah milik pemerintah Kota Bekasi sehingga menimbulkan kerugian negara adalah perbuatan 
yang dianggap dilakukan oleh PT CND. Artinya bahwa PT CND mengizinkan direktur melakukan perbuatan demikian. Corak pandang seperti ini hampir sama dengan pandangan hakim Denning dalam perkara Bolton Enginering Co Ltd v. Graham \& Sons Ltd di Amerika Serikat, director and managers who represent the directing and will of the company and control what it does. The state of mind of these managers ide the state of mind of the company andi is treated by the law as such (Cremona, 1989:65).

Keempat, mengenai pidana pokok berupa denda. Majelis hakim dalam amar putusannya menjatuhkan pidana denda kepada PT CND sejumlah Rp. 700.000.000,- Apabila dicermati, maka jumlah pidana denda tersebut tidak jauh berbeda dengan tuntutan JPU yakni sebesar Rp. 800.000.ooo,-- Jumlah ini masih terpaut jauh nilainya bila dibandingkan dengan kerugian negara yang ditaksir mencapai Rp. 4. 189.570.000,- Dengan demikian, putusan a quo belum mencerminkan upaya mengembalikan kerugian keuangan negara akibat perbuatan terdakwa PT CND. Idealnya tuntutan JPU mengikuti nilai kerugian negara yang ditimbulkan ketika mengkonstruksi tuntutan pidana kepada PT CND sehingga majelis hakim pun akan menjatuhkan pidana yang maksimal.

Kelima, ihwal tidak dikenakannya pidana tambahan kepada PT CND. Dalam menangani perkara yang melibatkan korporasi, salah satu hal yang paling krusial adalah mengenai pidana tambahan kepada korporasi. Hal ini dirasa sangat penting sebab dapat membantu memulihkan kerugian keuangan negara atau dapat juga memberikan efek jera kepada pelaku tindak pidana. Dalam Pasal 18 UU No. 31 Tahun 1999 jo UU No. 20 Tahun 2001 tentang Pemberantasan Tindak Pidana Korupsi, telah diatur mengenai pidana tambahan terhadap korporasi, misalnya: perampasan barang bergerak yang berwujud atau tidak berwujud, termasuk barang yang tidak bergerak; pembayaran uang pengganti yang jumlahnya sama dengan harta benda yang diperoleh dari tindak pidana korupsi; dan penutupan seluruh atau sebagian perusahaan untuk waktu paling lama 1 tahun; serta pencabutan seluruh atau sebagian hak-hak tertentu atau penghapusan sebagian keuntungan tertentu.

Sehingga ketika JPU tidak menuntut pidana tambahan kepada PT CND. Majelis hakim pun tidak mengambil terobosan dengan cara mengenakan sanksi pidana tambahan kepada PT CND. Padahal ada sanksi yang tersedia dan berguna bagi PT CND misalnya: penutupan 
seluruh atau sebagian perusahaan atau pidana pembayaran uang pengganti. Dengan cara ini selain memulihkan kerugian keuangan negara, juga dapat memberikan efek jera baik kepada PT CND maupun korporasi lain yang ingin melakukan tindak pidana korupsi.

Berdasarkan uraian kedua putusan tersebut, penulis berpandangan bahwa dalam putusan PT GJW dikatakan sebagai suatu karya pengadilan yang berani dan bertanggungjawab. Sebab sejak UU Tipikor diberlakukan, belum ada satu korporasi pun yang dikenai tuntutan pidana, kecuali dalam putusan PT GJW tahun 2010. Hal ini dapat dimaklumi sebab salah satu hambatan dalam menuntut korporasi adalah masih terpakunya aparat penegak hukum dengan asas geen straf zonder schuld atau tiada pidana tanpa kesalahan. Asas ini akan sulit diterapkan kepada korporasi sebab korporasi tidak memiliki kalbu atau akal sebagaimana halnya manusia. Dalam konteks suatu perseroan, penentuan kesalahan korporasi sangat mudah diidentifikasi yakni melalui kesalahan direksi atau dewan komisaris sebagaimana disebutkan dalam Pasal 1 angka 2 UU No. 40 Tahun 2007 tentang Perseroan Terbatas.

Padahal kesalahan atau mens rea adalah bagian yang paling elementer ketika berbicara mengenai pertanggungjawaban pidana, selain elemen actus reus atau perbuatan lahirnya. Namun demikian, dengan adanya UU antikorupsi dan perturan lain di luar KUHP yang telah mengakui korporasi sebagai subjek delik termasuk pengaturan pertanggungjawaban pidananya maka hal itu seharusnya tidak lagi menjadi hambatan serius. Kondisi terkini Mahkamah Agung telah mengeluarkan PERMA No. 13 Tahun 2016 tentang Tata Cara Penanganan Tindak Pidana Oleh Korporasi. Lebih teknis lagi, Kejaksaan Agung bahkan menerbitkan Surat Edaran No. 36 Tahun 2009 perihal korporasi sebagai tersangka/terdakwa dalam tindak pidana korupsi.

\section{PENUTUP}

\section{Simpulan}

Berdasarkan uraian terhadap dua putusan di atas mengani pembuktian kesalahan korporasi maka, ada beberapa poin penting sebagai kesimpulan. Pertama, putusan PT GJW adalah karya monumental pengadilan yang mampu memidana korporasi sehingga dapat dijadikan sebagai yurisprudensi bagi pengadilan lain yang 
menangani keterlibatan korporasi dalam tindak pidana korupsi. Kedua, dalam menentukan kesalahan korporasi, kedua putusan tersebut menitikberatkan pada kesalahan yang dilakukan oleh pengurus korporasi, seperti direktur. Kesalahan direktur adalah juga sebagai kesalahan korporasi. Ketiga, dikaitkan dengan teori pertanggungjawaban pidana korporasi maka majelis hakim pada dua perkara korupsi tersebut telah mengadopsi teori identifikasi. Keempat, perbuatan melawan hukum yang merugikan keuangan negara dan dilakukan direktur sebagai pengurus dianggap sama dengan yang dilakukan korporasi.

Kelima, mengenai sanksi pidana pokok, dalam dua putusan $a$ quo adalah sama yakni pidana denda. Keenam, mengenai sanksi pidana tambahan ada perbedaan. Dalam putusan PT GJW selain pidana pokok, korporasi juga masih dikenai pidana tambahan berupa penutupan seluruh atau sebagian perusahaan. Sedangkan dalam putusan PT CND tidak ada sama sekali sanksi pidana tambahan yang dikenakan kepada terdakwa. Ketujuh, kedua putusan tersebut, tidak memuat pidana tambahan berupa pembayaran uang pengganti, padahal sebagaimana diketahui bahwa salah satu cara memulihkan kerugian keuangan negara adalah melalui pidana pembayaran uang pengganti.

\section{Saran}

Adapun saran yang dapat penulis sampaikan dalam kajian ini adalah sebagai berikut: pertama, aparat penegak hukum khususnya KPK seharusnya tidak perlu ragu menersangkakan atau menuntut pidana korporasi yang terlibat dalam tindak pidana korupsi sebab selain sudah diatur dalam UU Tipikor, sudah diatur juga dalam 2 peraturan tekni yakni PERMA No. 13 Tahun 2016 tentang Tata Cara Penanganan Tindak Pidana Oleh Korporasi dan SE Jaksa Agung No. 36 Tahun 2009 perihal Korporasi sebagai tersangka/terdakwa dalam tindak pidana korupsi. Kedua, MA, Kejagung dan KPK secara rutin memberi pelatihan kepada penyidik, penuntut dan hakimnya agar lebih memahami penuntutan kepada korporasi. Ketiga, pemerintah merevisi UU antikorupsi dengan mereformulasi ketentuan proses pertanggungjawaban pidana korporasi dalam tindak pidana korupsi secara detail. 


\section{REFERENSI}

Amrullah, M.A. 2018. Perkembangan Kejahatan Korporasi: Dampak dan Permasalahan Hukumnya. Kencana Pernada Media Group. Jakarta.

Asworth, A dan Horder, J. 2013. Principle of Criminal Law. Cambridge University Press. New York.

Black, C.H. 1968. Blacks Law Dictionary: Definition of the Terms and Phrases of American and English Jurisprudence Ancient and Modern. West Publishing. New York.

Braithwaite, J. 1994. Corporate Crime in the Pharmaceutical Industry. Routledge and Kegan Paul. London.

Brodowski, Espinoza, M and Tiedemann K. 2014. Regulating Corporate Criminal Liability. Springer Heidelberg. New York

Cohen, M.L dan Olson, K.C. 1992. Legal Research. West Thompson Publishing. New York.

Clarkson dan Keating. 2007. Criminal Law: Text and Material. Sweet and Maxwell. London.

Cremona, M. 1989. Criminal Law. Macmillan Education Ltd. London.

Dennis, I. 2007. The Law of Evidence. Sweet and Maxwell. London.

Fisse, B and Braithwaite, J. 2013. Corporations, Crime and Accountability. Cambridge University Press. New York.

Fukuyama, F. 2014. Political Order and Political Decay: From The Industrial Revolution to the Globalization of Democracy. Farrar Straus \& Giroux. New York.

Hamzah, A. 2007. Pemberantasan Korupsi Melalui Hukum Pidana Nasional dan Internasional. PT Raja Grafindo Persada. Jakarta.

Harhap, M.Y. 2000. Pembahasan Permasalahan dan Penerapan KUHAP (Penyidikan dan Penuntutan). Sinar Grafika. Jakarta.

Hiariej, E. O.S. 2012. Teori dan Hukum Pembuktian. Erlangga. Jakarta.

. 2014. Prinsip-Prinsip Hukum Pidana. Cahya Atma Pustaka. Yogyakarta.

Huda, C. 2008. Dari Tiada Pidana Tanpa Kesalahan Menuju Kepada Tiada Pertanggungjawaban Pidana Tanpa Kesalahan. Kencana Pernada Media Group. Jakarta. 
Kadish, S.H. 1983. Encyclopedia of Crime and Justice (Vol 1). The Free Press Macmillan Publisher. New York.

Lafave, W.R. 2010. Principle of Criminal Law. West A Thomson Bussines. New York.

Marzuki, P.M. 2014. Penelitian Hukum. Kencana Pernada Media Group. Jakarta.

Mcleod, T.I. 1999. Legal Theory. Macmillan. London.

Moeljatno. 2008. Asas-Asas Hukum Pidana. Rineka Cipta. Jakarta.

Poernomo, B. 1993. Pokok-Pokok Tata Acara Peradilan Pidana Indonesia dalam UU RI No. 8 Tahun 1981.Liberty. Yogyakarta 1993. Asas-Asas Hukum Pidana. Ghalia Indonesia. Jakarta.

Poerwadarminta, W.J.S. 2007. Kamus Umum Bahasa Indonesia. Balai Pustaka. Jakarta.

Reid, S.T. 1995. Criminal Law. Prentice Hall. New Jersey.

Remmelink, J. 2003. Hukum Pidana: Komentar atas Pasal-Pasal Terpenting dalam Kitab Undang-Undang Hukum Pidana Belanda dan Padanannya dalam Kitab Undang-Undang Hukum Pidana Indonesia. Gramedia Pustaka Utama. Jakarta.

Sahetapy, J.E. 2002. Kejahatan Korporasi. Refika Aditama. Bandung.

Satria, H. 2017. Penerapan Pidana Tambahan dalam Pertanggungjawaban Pidana Korporasi Pada Tindak Pidana Lingkungan Hidup. Jurnal Yudisial 10 (2): 155-171.

Schaffmeister, D, Keijzer, N, dan Sutorius, E.P.H. 1995. Hukum Pidana (Diterjemahkan oleh J.E. Sahetapy). Liberty. Yogyakarta.

Simpson, S.S. 2005. Corporate Crime, Law and Social Control. Cambridge University Press. New York.

Simpson, S.S dan Weisburd, D. 2009. The Criminilogy of White Collar Crime. Springer. New York.

Sjahdeini, S.R. 2017. Ajaran Pemidanaan: Tindak Pidana Korporasi dan Seluk Beluknya. Kencana Pernada Media Group. Jakarta.

Sjawie, H.F. 2013. Direksi Perseroan Terbatas serta Pertanggungjawaban Pidana Korporasi. Citra Aditya Bakti. Bandung.

Smith, J.C dan Hogan, B. 1998. Criminal Law. Butterworths. London. 
Stone, J.R. 2005. Dictionary of Latin Quotations. Routledge. London and New York.

Sudarto. 2007. Hukum dan Hukum Pidana. Alumni. Bandung. 